\title{
Insight and psychotic experiences in patients with non-psychotic depression
}

\author{
Psikotik bulgulu olmayan depresyon hastalarında içgörü ve psikotik \\ yaşantılar
}

Oğuzhan Herdi', Oğuz Erkan Berksun²

${ }^{1}$ M.D., Antalya Serik State Hospital, Antalya, Turkey https://orcid.org/0000-0003-0101-2663

2Prof., Ankara University Faculty of Medicine, Department of Psychiatry, Turkey https://orcid.org/0000-0001-6587-9392

\begin{abstract}
SUMMARY
Objective: The relationship between psychotic symptoms and insight is repeatedly shown. Studies intended to present the relationship between insight and psychosis are mostly conducted on psychotic disorders. However, knowledge about psychotic experiences (PEs) and insight is limited for non-psychotic disorders, like depression. It was aimed to compare patients with nonpsychotic depression and healthy controls in terms of insight and investigate the relationship between insight and PEs. Method: 49 patients with depression and 42 healthy controls were included. Sociodemographic Data Form, Hamilton Depression Rating Scale (HAM-D), Beck Anxiety Inventory(BAI), Self-reflection and Insight Scale (SRIS), Community Assessment of Psychic Experiences (CAPE42) and Beck Cognitive Insight Scale (BCIS) were applied to participants. Results: TLevels of PEs were significantly higher and levels of SRIS insight subscale were lower in patients with depression than healthy controls. There were significant negative correlations between SRIS insight subscale and levels of PEs. Levels of PEs were predicted by scores of HAM-D, BAI and SRIS insight subscale, but BAI was the only variable which maintained significance in multiple regression analysis. Discussion: Patients with non-psychotic depression could manifest impaired insight and a mild form of psychotic features and there is a relationship between these two psychiatric phenomena.
\end{abstract}

Key Words: Psychotic experiences, insight, depression, anxiety
ÖZET

Amaç: Psikotik belirtiler ve içgörü arasındaki ilişki defalarca gösterilmiştir ve bu çalışmalar çoğunlukla psikotik bozukluğu olan hastalarda yürütülmüştür. Ancak depresyon gibi psikotik olmayan bozukluklarda psikotik özellikler ve içgörü hakkındaki bilgimiz kısıtlıdır. Bu çalışmada, psikotik olmayan depresyon hastaları ve sağlıklı kontrolleri içgörü açısından karşılaştırmayı ve bu hasta grubunda psikotik yaşantılar (PY) ile içgörü arasındaki ilişkiyi incelemeyi amaçlamaktayız. Yöntem: 49 depresyon hastası ve 42 sağlıklı kontrol çalışmaya dahil edilmiştir. Sosyodemografik Veri Formu, Hamilton Depresyon Ölçeği (HDÖ), Beck Anksiyete Envanteri (BAE), Kendine Yansıtma ve İçgörü Ölçeği (KYiÖ), Toplumda Psikoz Benzeri Yaşantıları Değerlendirme Ölçeği (CAPE42) ve Beck Bilişsel İçgörü Ölçeği (BBï)) katılımcılara uygulanmıştır. Bulgular: PY düzeyi depresyon hastalarında daha yüksekken KYiÖ içgörü ölçeği anlamlı olarak daha düşüktür. KYiÖ içgörü ölçeği ile PBY düzeyi arasında anlamlı olarak ters korelasyon mevcuttur. PBY düzeyi regresyon analizinde HDÖ, BAE ve KYiÖ içgörü ile anlamlı olarak öngörülürken modelde sadece $B A E$ anlamlılığını devam ettirmiştir. Sonuç: Psikotik olmayan depresyon hastalarında içgörüde bozulma ve ılımlı psikotik belirtiler gözlenmektedir ve bu iki fenomen arasında anlamlı bir ilişki mevcuttur.

Anahtar Sözcükler: Psikotik yaşantılar, içgörü, depresyon, anksiyete

(Turkish J Clinical Psychiatry 2021;24:307-314)

DOI:10.5505/kpd.2021.67625 


\section{INTRODUCTION}

Relationship between psychotic symptoms and insight is repeatedly shown and some authors have been indicated that insight is an important factor for development and continuity of psychosis $(1,2)$. Studies intended to present the relationship between insight and psychosis have been conducted on psychotic disorders such as schizophrenia spectrum disorders and bipolar disorder. However, increasing evidence and knowledge show that psychiatric symptoms or phenomena are spectra. So, different levels or forms of the symptoms could be observed in all psychiatric disorder.

An example of spectrums is 'psychosis continuum', which describes a psychotic spectrum including several levels of psychosis from sub-threshold or subclinical psychosis to clinically explicit psychosis $(3,4)$. Psychotic experiences (PEs), which perception abnormalities, delusional ideations and magical thoughts that do not reach clinical level, are one of these levels (5). PEs could be observed not only in patients with psychotic disorders but also in general population with no sign of a psychiatric disorder and, hence often do not require any treatment $(4,5)$. There are few studies reporting that PEs are more frequent among patients with depression and anxiety disorders, furthermore, positive correlation between levels of these experiences and severity of depression was found(6-8). Bidirectional relationship between mood episodes and psychotic experiences was observed in a community based, 6-year follow-up study from Turkey (9). However, to our knowledge, no study has investigated the association between these experiences and insight in neither psychotic disorders nor non-psychotic disorders.

Insight has multiple and overlapping definitions. As a comprehensive definition, insight is the ability to understand/be aware of the objective reality of self that comprises awareness to own thoughts, emotions, behaviours, mental disorder, unusual mental events like delusions and hallucinations and, recognition to treatment need $(10,11)$. Considering this comprehensive definition, authors have developed scales that evaluate different parts of insight, such as clinical, cognitive, and therapeu- tic insight. Most of the studies have been reported about lack of insight or impaired insight in patients with psychotic disorders, but, the results of studies aimed to investigate insight in patients with nonpsychotic disorders are conflicted. However, we have observed distorted awareness of the objective reality of self in patients with non-psychotic depression in our clinic experiences.

Given the observed relationship between insight and psychotic symptoms and our clinical experience on insight, we aimed to compare patients with non-psychotic depression and healthy controls in terms of insight and investigate the relationship between insight and PEs in patients with non-psychotic depression in this study.

\section{METHOD}

\section{Study Sample and Study Design}

This cross-sectional, single-centre study was conducted at adult psychiatry outpatient clinic of a university hospital. Forty-nine patients with depression and forty-two healthy controls (HC) were included.

\section{Patients with Depression}

Patients who were examined and diagnosed with depression by physicians who were blind to study design were referred to one of the authors (O.H) to further evaluations. Patients who were aged between 18-65 years, graduated at least preliminary school, volunteer to participate the study, did not have comorbid psychiatric disorder including alcohol and drug dependency, intellectual disability, schizophrenia spectrum disorders, schizotypal or schizoid personality traits or disorders were selected for clinical interview. To rule out the possible effect of antipsychotics or mood stabilizer drugs on PEs, patients who have ever used antipsychotics and mood stabilizer drugs were excluded. In the clinical interview, first, patients were questioned for bipolar disorder depressive episode, then, patients who were suspected of bipolar disorder were excluded. After these exclusion processes, Hamilton Depression Rating Scale (HAM-D) was 
applied to make certain of depression diagnosis and Psychotic Depression Assessment Scale to exclude explicit psychotic features. Totally fortynine patients were selected to patients with depression group and the self-report scales were given to patients to fill.

\section{Healthy Controls}

Psychiatrically healthy controls were selected from relatives and neighbourhoods of hospital staff and medical students. The detailed clinical interview was made by one of the authors (O.H.) to rule out any recent or former psychiatric disorder. Individuals who were aged between 18-65 years, graduated at least preliminary school, volunteer to participate study, never diagnosed with any mental disorder and never used psychotropic drugs were selected for application of scales. Forty-two individuals were selected for the healthy controls group. First, HAM-D and sociodemographic data form were applied to participants. Then, self-report scales were given to fill.

Both verbal and written informed consents were obtained from all participants.

\section{Measures}

Sociodemographic Data Form: This form was developed by researchers to record age, gender, graduation, marital status, occupational status and duration of psychotropic drug use.

Hamilton Depression Rating Scale (HAMD-D): The scale was developed by Hamilton and translated to Turkish by Akdemir et al. $(12,13)$. The scale has a total of 17 questions and one could get a maximum of 53 points. 14 points and more indicate depression.

Beck Anxiety Inventory (BAI): The inventory was developed by Beck and translated to Turkish by Ulusoy et al. $(14,15)$. It consists of 21 items with a 4 Likert scale and raw scores ranging from 0 to 63 . BAI scores are classified as minimal anxiety ( 0 to 7 ), mild anxiety (8 to 15$)$, moderate anxiety (16 to 25 ), and severe anxiety (30 to 63 ).
Community Assessment of Psychic Experiments (CAPE42): CAPE 42 was developed by Konings et al. and its Turkish validity and reliability study was conducted by Saka et al. in the context of "European Network of National Schizophrenia Networks Studying Gene-Environment Interactions, Turkey Schizophrenia Network Study" $(16,17)$. The scale is a 42 -item self-report questionnaire that measures PEs in the general population. It has three dimensions; positive, negative, depression and two parts; frequency and distress. Both frequency and distress part of the scale is 4 Likert and raw scores for each part ranging from 42-168. In this study, only the 20-itemed positive dimension of the scale was used. The negative dimension, depression dimension and distress part of CAPE42 was not used due to overlapping with HAM-D and BAI.

\section{Measuring Insight}

In this study, two different scales were used to assess insight.

Self-Reflection and Insight Scale (SRIS): SRIS was developed by Grant et al. and its Turkish reliability and validity were made by Yavasoglu $(18,19)$. It has two subscales: self-reflection and insight. It consists of 20 questions with a 6 Likert scale. The selfreflection subscale has 12 questions and others rate insight. Higher scores indicate a higher level of selfreflection and insight. In this study, insight subscale was included to analyze.

Beck Cognitive Insight Scale (BCIS): BCIS was developed by Beck et al. and its Turkish reliability and validity study was made by Aslan et al. $(20,21)$. It has two dimensions: self-reflectiveness (S-Refs) and self-certainty (S-Cer). It consists of 15 questions and total scores are calculated by subtracting S-Cer from S-Refs. In this study, both total scores and subscale scores separately were used in analyses. Higher scores indicate higher levels of cognitive insight.

To prevent conceptual confusion, we used 'psychological insight' for insight which assesses in SRIS insight subscale and 'cognitive insight' for insight 
which assesses in BCIS.

Psychotic Depression Assessment Scale (PDAS): PDAS was used to exclude the diagnosis of psychotic depression. Scores of this scale were not used in analyzes.

\section{Statistical Analysis}

Sociodemographic variables were analyzed with Chi-Square, Student's-t or Mann-Whitney U according to features of variables. To compare scores of CAPE 42 positive dimension (CAPE42 PD), HAM-D, BAI, SRIS insight subscale, BCIS and subscales between patients with depression and HC, Mann-Whitney U or Student's t-test were used according to distribution patterns.

Rest of analyzes were conducted only in patients with depression group. To investigate the relationship between scores CAPE42 positive dimension and HAM-D, BAI, SRIS insight subscale, BCIS and subscales, Pearson or Spearman correlation analyzes were performed according to distribution patterns of variables. Multiple regression analyzes were performed to investigate the predictive effect of levels of depression, anxiety and insight on levels of PEs. Finally, patients with depression were separated into two groups in terms of medication use. Patients who have used antidepressant medications more than one month were included 'currently on medication' $(n=27)$ and patients who have used antidepressants medication less than one month or new-onset depression were included 'recently diagnosed' $(n=22)$. Scale scores were compared between these two groups.
SPSS 21.0 belonged to IBM was used for statistical analysis and $\mathrm{p}<0,05$ was accepted for statistical significance.

\section{Ethical Approval}

Ethical Approval was received from Ankara University Faculty of Medicine Human Researches Ethical Committee.

\section{RESULTS}

Sociodemographic variables and their comparison between patients with depression and HC were presented in Table 1.

Level of depression, anxiety, CAPE 42 PD and total score of BCIS were higher in patients with depression $(p<0,001, p<0,001$ and $p=0,007$, $\mathrm{p}=0,001$ respectively). The insight subscale of SRIS and the self-certainty subscale of BCIS scores were higher in the control group $(p<0,001$, $\mathrm{p}=0,015$ respectively). Comparisons of HAM-D, BAI, CAPE42PD, SRIS insight subscale, BCIS scores between groups were presented in Table 2 .

In patients with depression, levels of HAM-D and BAI were lower in patients with 'currently on medication' in comparison with 'recently diagnosed' $(\mathrm{p}<0,001$ and $\mathrm{p}=0,020$ respectively). However, there was no difference for other scales' scores between 'currently on medication' and 'recently diagnosed' (Table 3).

In patients with depression there were negative

Table 1. Sociodemographic Features and Comparison of Patients with Depression and Healthy Control Groups

\begin{tabular}{|c|c|c|c|c|c|c|}
\hline & \multicolumn{2}{|c|}{$\begin{array}{l}\text { Patients with depression } \\
(\mathrm{n}=49) \\
(\mathrm{Mean}-\mathrm{SD})\end{array}$} & \multicolumn{2}{|c|}{$\begin{array}{l}\mathrm{HC} \\
(\mathrm{n}=42) \\
(\mathrm{Mean}-\mathrm{SD}) \\
\end{array}$} & $\mathrm{x}^{2} / \mathrm{t}$ & $\mathrm{p}$ \\
\hline Age & 40 . & & 39. & & -0.698 & 0.512 \\
\hline Education (years) & 10 . & & 11. & & 0.615 & 0.481 \\
\hline Gender & $\mathrm{n}$ & $\%$ & $\mathrm{n}$ & $\%$ & & \\
\hline Female & 41 & 83.7 & 35 & 83.3 & 0.002 & 0.965 \\
\hline Male & 8 & 16.3 & 7 & 16.7 & & \\
\hline \multicolumn{7}{|l|}{ Marital Status } \\
\hline Married & 38 & 77.6 & 30 & 71.4 & 1.135 & 0.567 \\
\hline Single & 9 & 18.4 & 8 & 19 & & \\
\hline Divorced & 2 & 4.1 & 4 & 9.5 & & \\
\hline \multicolumn{7}{|l|}{ Occupational Status } \\
\hline Employed & 20 & 40.8 & 40 & 95.2 & 29.821 & $<0,001 *$ \\
\hline Unemployed & 29 & 59,2 & 2 & 4.8 & & \\
\hline
\end{tabular}

Turkish J Clinical Psychiatry 2021;24:307-314 
Herdi O, Berksun OE.

Table 2. Comparison of HAM-D, BAI, CAPE42PD, SRIS Insight subscale, BCIS Between Patients with Depression and Healthy Control Groups

\begin{tabular}{lllc}
\hline & $\begin{array}{l}\text { Patients with Depression } \\
(\mathrm{n}=49)\end{array}$ & Healthy Control (n=42) & \\
& $\begin{array}{l}\text { Mean-SD /Median (min- } \\
\text { max) }\end{array}$ & $\begin{array}{l}\text { Mean-SD /Median (min- } \\
\text { max) }\end{array}$ & P \\
\hline HAM-D & $21.44-6.90$ & $2.52-3.41$ & 16.136 \\
BAI & $21(0-53)$ & $4(0-32)$ & -5.838 \\
CAPE42PD & $28(20-53)$ & $25(20-38)$ & -2.674 \\
SRIS Insight subscale & $29.51-6.90$ & $35.52-6.22$ & $0.001^{*}$ \\
BCIS Total & $2.63-4.51$ & $-0.71-4.79$ & -4.332 \\
Self-reflectiveness & $10.75-4.48$ & $9.30-4.73$ & 3.427 \\
Self-certainty & $8.12 / 8-3.83$ & $10.02 / 10-3.41$ & $0.001^{*}$ \\
\hline
\end{tabular}

HAM-D: Hamilton Depression Rating Scale. BAI: Beck Anxiety Inventory. CAPE42PB: Community Assessment of Psychi Experiences Positive Dimension. SRIS:Self-Reflection and Insight Scale. BCIS: Beck Cognitive Insight Scale. SD: Standard Deviation

For comparison between groups Student s t test was used for variables show normal distribution pattern. Mann-Whitney U was used for variables not show normal distribution pattern $\mathrm{P}<0.05$

correlation between age and levels of PEs $(\mathrm{p}=0,009, \mathrm{r}=-0,370)$ and positive correlation between graduation and levels of PEs $(p=0,035$, $r=0,302)$. There was no relationship between other sociodemographic variables and levels of PEs.

Correlations between HAM-D, BAI, CAPE42PD, SRIS insight subscale, and BCIS scores in patients with depression were shown in Table 4. Multiple regression analysis was performed to predict levels of PEs in patients with depression. The model consisted of HAM-D, BAI and SRIS insight subscale. These variables significantly predicted levels of PEs $(\mathrm{F}=8,987 \mathrm{p}<0,001)$ and explained $33,3 \%$ of variance $(\mathrm{R}=0,612, \mathrm{R} 2=0,375$, Adjusted $\mathrm{R} 2=0,333)$. Only BAI significantly added to the model $(\mathrm{p}=0,001)$ (Table 5).

\section{DISCUSSION}

In this paper, we observed that levels of psychological insight were lower in patients with depression in comparison with healthy controls, in addition to a negative correlation between levels of PEs and psychological insight in patients with depression group. Also, it was shown that cognitive insight levels were higher in patients with depression than healthy controls. However, although there was a positive correlation between BCIS self-reflectiveness subscale and PEs, similarly between BCIS selfcertainty subscale and PEs, there was no correlation between levels of cognitive insight and PEs. In regression analyze, levels of depression, anxiety and psychological insight significantly predicted levels of PEs, but of all, only levels of anxiety was the variable that maintained significance in the model.

Our starting point was that if patients with non-psychotic depression can have mild forms of psychotic features, like PEs, and if insight is an important factor for development and continuity of psychosis, there should be a relationship between PEs and impairments in insight. So, we first aimed to show

Table 3. Comparison of HAM-D, BAI, CAPE42PD, SRIS Insight subscale, BCIS between Recently Diagnosed and Currently on Medication in Patients with Depression Group

\begin{tabular}{|c|c|c|c|c|}
\hline & $\begin{array}{l}\text { Currently on medication } \\
(\mathrm{N}=27) \\
\text { Mean-SD /Median (min- } \\
\max )\end{array}$ & $\begin{array}{l}\text { Recently Diagnosed } \\
(\mathrm{N}=22) \\
\text { Mean-SD /Median } \\
(\min -\max )\end{array}$ & $\mathrm{z} / \mathrm{t}$ & $\mathrm{P}$ \\
\hline HAM-D & $18.03-5.98$ & $25.63-5.59$ & 4.552 & $<0.001^{*}$ \\
\hline BAI & $17(0-45)$ & $29.05(1-53)$ & -2.333 & $0.020 *$ \\
\hline CAPE42PD & $27(20-53)$ & $28.50(21-51)$ & -1.642 & 0.101 \\
\hline SRIS Insight & $30.55-7.23$ & $28.22-6.40$ & -1.178 & 0.245 \\
\hline BCIS Total & $2.00-3.81$ & $3.40-5.23$ & 1.089 & 0.282 \\
\hline Self-reflectiveness & $10.40-4.38$ & $11.18-4.66$ & 0.597 & 0.553 \\
\hline Self-certainty & $8.40-3.78$ & $7.77-3.95$ & -0.572 & 0.570 \\
\hline
\end{tabular}

HAM-D: Hamilton Depression Rating Scale. BAI: Beck Anxiety Inventory. CAPE42PB: Community Assessment of Psychi Experiences Positive Dimension. SRIS:Self-Reflection and Insight Scale. BCIS: Beck Cognitive Insight Scale. SD: Standard Deviation

For comparison between groups.Student s t test was used for variables show normal distribution pattern. Mann-Whitney U was used for variables not show normal distribution pattern $\mathrm{P}<0.05$ 
Insight and psychotic experiences in patients with non-psychotic depression

Table 4. Correlations Between HAM-D, BAI, CAPE42PD, SRIS Insight Subscales, BCIS in Patients with Depression Group

\begin{tabular}{lllllll}
\hline & CAPE42PB & \multicolumn{3}{c}{ HAM-D } & BAI & $\mathrm{p}$ \\
\hline HAM-D & $\mathrm{r}$ & $\mathrm{P}$ & $\mathrm{r}$ & $\mathrm{p}$ & 0.544 & $<0.001^{*}$ \\
BAI & 0.371 & $0.009^{*}$ & - & - & - & - \\
SRIS Insight & 0.629 & $<0.001^{*}$ & 0.523 & $0.000^{*}$ & -0.372 & $0.009^{*}$ \\
BCIS & -0.440 & $0.002^{*}$ & -0.263 & 0.068 & 0.192 & 0.187 \\
S-Ref & 0.175 & 0.228 & 0.156 & 0.285 & 0.254 & 0.079 \\
S-Cer & 0.463 & $0.001^{*}$ & 0.140 & 0.339 & 0.100 & 0.494 \\
\hline
\end{tabular}

HAM-D: Hamilton Depression Rating Scale. BAI: Beck Anxiety Inventory. CAPE42PB: Community Assessment of

Psychic Experiences Positive Dimension. SRIS:Self-Reflection and Insight Scale. BCIS: Beck Cognitive Insight Scale (S-

Ref:Self-reflectiveness. S-Cer:Self-certainty). Pearson correlation analysis was used for variables show normal distribution pattern. Spearman correlation analysis was used for variables not show normal distribution pattern. $r=$ correlation coeffciency $* \mathrm{P}<0.05$

impairments in insight by SRIS insight subscale and BCIS. SRIS is focused on evaluating one's awareness of his/her own thoughts, emotions and behaviours (psychological insight) (22). On the other hand, BCIS is focused on evaluating one's willingness to examine what one mentally produces, acceptance of fallibility (self-reflectiveness) and one's overconfidence to the validity of own beliefs (self-certainty) (cognitive insight) (21). In this paper, whereas levels of psychological insight were lower in patients with depression, levels of cognitive insight were higher comparing with healthy controls. These findings indicate that patients with depression could manifest impairments in awareness of his/her own thoughts, emotions and behaviours, but not in cognitive insight. According to BCIS, high level of self-reflectiveness and low level of self-certainty point out better cognitive insight (21). Patients with depression had higher levels of self-reflectiveness and lower levels of self-certainty compared with healthy controls in this study. These findings indicate that patients with depression are more willing to admit they could be wrong but less confident about their beliefs. Similar to our findings, Van Camp et al observed that levels of self-reflectiveness are higher in patients with depression (23), while Weintraub et al. showed that high levels of self-certainty are related to decreased depression and increased life quality (24). However, to our knowledge, SRIS has been never used to evaluate insight in patients with depression, as we did.

Next, we aimed to show the relationship between levels of PEs and levels of insight. There was a negative correlation between levels of PEs and levels of psychological insight, whereas cognitive insight was not correlated with levels of PEs. However, both self-reflectiveness and self-certainty had a positive correlation with levels of PEs. Psychological insight is considered as a part of private self-consciousness (25). Smari et al. were reported that paranoia is related to private selfconsciousness and social anxiety (26). A study showed that PEs are more common in individuals with high levels of self-shame and self-criticism (27). Regarding with cognitive insight, individuals with delusions have low levels of self-reflectiveness and high levels of self-certainty although both levels of self-certainty and self-reflectiveness are high in individuals with nonclinical delusion proneness (28). Similar results have been reported for undergraduate students with no history of a psychotic disorder (29). In the lights of these findings and current literature, we proposed that while impairments in psychological insight could point out mild impairments, impairments in cognitive insight could indicate more severe impairments in insight (10). So, both psychosis and impairments in insight are spectra and these two spectrums are positively correlated. Furthermore, mild forms of these two spectra could be observed in patients with more neurotic disorders, like non-psychotic depression, and severe forms in patients with more psychotic disorders. Finally, not observing a correlation between SRIS insight subscale and BCIS supports our proposition.

Table 5. Multiple Linear Regression Analysis for CAPE42PD in Patients with Depression Group

\begin{tabular}{|c|c|c|c|c|c|}
\hline & B & SE & Beta & $\% 95 \mathrm{CI}$ & $\mathrm{P}$ \\
\hline HAM-D & 0.058 & 0.163 & 0.049 & $-0,271-0,386$ & 0.725 \\
\hline BAI & 0.274 & 0.084 & 0.465 & $-0,565-0,032$ & $0.002 *$ \\
\hline SRIS Ins & -0.267 & 0.148 & -0.227 & $0,104-0,444$ & 0.079 \\
\hline
\end{tabular}

HAM-D: Hamilton Depression Rating Scale. BAI: Beck Anxiety Inventory. CAPE42PB: Community Assessment of Psychic Experiences Positive Dimension. SRIS:Self-Reflection and Insight Scale(Ins:Insight). $* \mathrm{P}<0.05$

Turkish J Clinical Psychiatry 2021;24:307-314 
Although being on antidepressant treatment more than one month was effected on levels of depression and anxiety, it was not effected on levels of PEs and insight. However, this study was not an intervention study. To our knowledge, no study has investigated effects of antidepressant treatment on insight or PEs. Considering our findings, while antipsychotics could relief depression by reducing levels of PEs, psychotherapies could play a role by strengthening insight. Effects of treatment on PEs and insight could be a topic of further researches.

Levels of depression, psychological insight and anxiety significantly predicted levels of PEs in this study, but anxiety was only variable maintained significance. Several studies reported a positive correlation between levels of PEs, anxiety and depression $(6,7,8,30)$. In a German cohort, a doseresponse relationship was observed between affective dysregulation and psychotic experiences. Moreover, it has been also reported that there is a bidirectional relationship between psychotic-experiences and mood episodes (9). Relationship between anxiety and psychotic symptoms has been shown repeatedly (31-33). Extended and transdiagnostic psychosis phenotype has been proposed to bring in new understanding for PEs in general population (34). The phenotype offers broad perspective for psychosis spectrum and its relationship with affective symptoms. However, while the phenotype is mainly about psychosis, an affective disorder was evaluated in terms of PEs in this study. So, considering our findings, a transdiagnostic phenotype for affective disorders could also exist. On the other hand, insight, which is related both development and continuity of psychosis, has not been considered for extended and transdiagnostic psychosis phenotype. In future researches, this issue could be evaluated.

There are some limitations to this study. First, small sample size has restricted the generalizability of our findings. Second, SRIS has been never used to evaluate insight in patients with depression. However, the questions of the scale are compatible with our experiences which patients with depression could have disturbed awareness of his/her own emotions, thought and behaviours. Third, the cross-sectional design of the study prevents to interpret causality. Forth, due to absence of follow- ups, interpretation about the effects of treatments on PEs and insight is insufficient. Fifth, even though there was no statistical difference between patients and healthy controls in terms of age, gender, marital status and education, not matching these two groups in terms of above-mentioned variables is a limitation. At last, a history of trauma, which is a related factor for PEs, was not evaluated.

Our study has also strength features. To our knowledge, this is the first study that shows the relationship between insight and PEs. Second, strict evaluation for choosing participants has allowed us to compare patients with non-psychotic depression and psychiatrically healthy individuals. Third, our findings are evidence for those psychiatric or psychological phenomena are not dichotomous, they are spectra, moreover, these spectra have associations between each other. Ineffectiveness of antidepressant treatment on levels of PEs and insight could contribute to widening lying mechanism under the effects of antipsychotics and psychotherapies.

As a conclusion, patients with non-psychotic depression have a mild form of psychotic features and impaired awareness of his/her own emotions, thoughts and behaviours. Also, this impaired awareness is related to PEs, and anxiety is an important factor for this relationship.

\section{Acknowledgement}

These findings were provided from the corresponding author's master thesis in medicine (Psychosis like experiences and their relationship with insight and self-reflection in major depression, 2019).

Correspondence address: M. D., Oguzhan Herdi, Antalya Serik State Hospital, Serik, Antalya, Turkey oguzhan2036@gmail.com 
Insight and psychotic experiences in patients with non-psychotic depression REFERENCES

1. Keshavan MS, Rabinowitz J, Desmedt G, Harvey PD, Schooler N. Correlates of insight in first episode psychosis. Schizophr Res 2004; 70: 187-194.

2. McEvoy JP, Johnson J, Perkins D, Lieberman JA, Hamer RM, Keefe RSE, Tohen M, Glick ID, Sharma T. Insight in firstepisode psychosis. Psychol Med 2006; 36: 1385.

3. DeRosse P, Karlsgodt KH. Examining the Psychosis Continuum. Curr Behav Neurosci Reports 2015; 2: 80-89.

4. Kaymaz N, Van Os J. Extended psychosis phenotype - Yes: Single continuum - Unlikely. Psychological Medicine 2010; 40: 1963.

5. Linscott RJ, Van Os J. An updated and conservative systematic review and meta-analysis of epidemiological evidence on psychotic experiences in children and adults: On the pathway from proneness to persistence to dimensional expression across mental disorders. Psychological Medicine 2013; 43: 1133.

6. Saha S, Scott J, Varghese D, McGrath J. Anxiety and depressive disorders are associated with delusional-like experiences: A replication study based on a National Survey of Mental Health and Wellbeing. BMJ Open 2012; 2: e001001.

7. Varghese D, Scott J, Welham J, Bor W, Najman J, O'Callaghan M, Williams G, McGrath J. Psychotic-like experiences in major depression and anxiety disorders: A populationbased survey in young adults. Schizophr Bull 2011; 37:389-393.

8. Wigman JTW, Van Nierop M, Vollebergh WAM, Lieb R, Beesdo-Baum K, Wittchen HU, Van Os J. Evidence that psychotic symptoms are prevalent in disorders of anxiety and depression, impacting on illness onset, risk, and severity Implications for diagnosis and ultra-high risk research. Schizophr Bull 2012; 38:247-257.

9. Kırlı U, Binbay T, Drukker M, van Os J, Alptekin K, Kayahan B, Elbi H. Psychotic experiences and mood episodes predict each other bidirectionally: a 6-year follow-up study in a community-based population. Soc Psychiatry Psychiatr Epidemiol 2019; 54:331-341.

10.Reddy M. Insight and psychosis. Indian Journal of Psychological Medicine 2015; 37: 257-260.

11. David AS. Insight and psychosis. Br J Psychiatry 1990; 156: 798-808.

12. Akdemir A, Türkçapar MH, Örsel SD, Demirergi N, Dag I, Özbay MH. Reliability and validity of the Turkish version of the Hamilton Depression Rating Scale. Compr Psychiatry 2001; 42: 161-165.

13. HAMILTON M. A rating scale for depression. J Neurol Neurosurg Psychiatry 1960; 23: 56.

14. Ulusoy M, Sahin NH, Erkmen H. The Beck anxiety inventory: psychometric properties. J Cogn Psychother 1998;12:163-72.

15. Beck AT, Epstein N, Brown G, Steer RA. An inventory for measuring clinical anxiety: psychometric properties. J Consult Clin Psychol 1988;56:893.

16. Konings M, Bak M, Hanssen M, Van Os J, Krabbendam L. Validity and reliability of the CAPE: A self-report instrument for the measurement of psychotic experiences in the general population. Acta Psychiatr Scand 2006; 114: 55-61.

17. Saka MC, Atbaşoğlu EC, Alptekin K. Şizofrenide GenÇevre Etkileşimi Çalışması İçin Avrupa Şizofreni Ağı Dahilinde Türkiye Şizofreni Ağı Aile Temelinde Gen Çevre Etkileşimi Çalışması: Çok Merkezli, Uluslararası, Müdahalesiz Laboratuvar Çalışması 2015.

Turkish J Clinical Psychiatry 2021;24:307-314
18. Grant AM, Franklin J, Langford P. THE SELF-REFLECTION AND INSIGHT SCALE: A NEW MEASURE OF PRIVATE SELF-CONSCIOUSNESS. Soc Behav Personal an Int J 2006; 30: 821-835.

19. Yavaşoğlu M. Kendine Yansitma ve İçgörü Ölçeğinin Türk Kültürüne Uyarlanması. Yayınlanmamış Yüksek Lisans Tezi. 2010.

20. Aslan S, Turkcapar H, Guney E, Eren N, Akkoca Y, Ugurlu M, Karakas G. The validity and reliability of the Turkish version of 'Beck Cognitive Insight Scale' in schizophrenic patient. Beck Bilissel Icgoru Olcegi Turkce Formunun Sizofrenik Hastalar Icin Guvenilirlik ve Gecerlik Calismasi 2005.

21. Beck AT, Baruch E, Balter JM, Steer RA, Warman DM. A new instrument for measuring insight: The Beck Cognitive Insight Scale. Schizophr Res 2004; 68: 319-329.

22. Grant AM, Franklin J, Langford P. The self-reflection and insight scale: A new measure of private self-consciousness. Soc Behav Pers 2002; 30: 821-835.

23. Van Camp L, Ameele S van den, Sabbe BGC, Oldenburg JFE. The longitudinal course of cognitive insight and mood in bipolar disorder. Psychiatry Res 2018; 269:9-12.

24. Weintraub MJ, Weisman de Mamani A. Effects of sub-clinical psychosis and cognitive insight on psychological well-being: A structural equation model. Psychiatry Res 2015; 226:149-155.

25. Creed AT, Funder DC. The two faces of private self-consciousness: Self report, peer-report, and behavioral correlates. Eur J Pers 1998;12: 411-431.

26. Smári J, Stefánsson S, Thorgilsson H. Paranoia, self-consciousness, and social cognition in schizophrenics. Cognit Ther Res 1994; 18: 387-399.

27. Scheunemann J, Schlier B, Ascone L, Lincoln TM. The link between self-compassion and psychotic-like experiences: A matter of distress? Psychology and Psychotherapy: Theory, Research and Practice 2018; 92: 523-538.

28. Carse T, Langdon R. Delusion proneness in nonclinical individuals and cognitive insight: The contributions of rumination and reflection. J Nerv Ment Dis 2013; 201: 659-664.

29. Warman DM, Martin JM. Cognitive insight and delusion proneness: An investigation using the Beck Cognitive Insight Scale. Schizophr Res 2006; 84: 297-304.

30. Rössler W, Hengartner MP, Ajdacic-Gross V, Haker H, Gamma A, Angst J. Sub-clinical psychosis symptoms in young adults are risk factors for subsequent common mental disorders. Schizophr Res 2011; 131: 18-23.

31. Freeman D, Pugh K, Antley A, Slater M, Bebbington P, Gittins M, Dunn G, Kuipers E, Fowler D, Garety P. Virtual reality study of paranoid thinking in the general population. $\mathrm{Br} \mathrm{J}$ Psychiatry 2008; 192: 258-263.

32. Freeman D, Garety PA. Worry, worry processes and dimensions of delusions: An exploratory investigation of a role for anxiety processes in the maintenance of delusional distress. Behav Cogn Psychother 1999; 27: 47-62.

33. Martin JA, Penn DL. Brief report Social cognition and subclinical paranoid ideation A number of social-cognitiv e and clinical constructs have been implicated in paranoid. Br J Clin Psychol 2001; 40:261-265

34. Van Os J, Reininghaus U. Psychosis as a transdiagnostic and extended phenotype in the general population. World Psychiatry 2016; 15: 118-124. 